\title{
PENGENALAN GERAKAN LITERASI PADA MASYARAKAT
}

\section{Sanusi, Agung Prasetyo}

Pendidikan Bahasa Inggris Fakultas Bahasa dan Seni Universitas Indraprasta PGRI

\begin{abstract}
Abstrak
Budaya Literasi harus terus dikembangkan mengingat bahwa melalui membaca maka kualitas pendidikan yang tinggi dapat tercipta. Dengan mengenalkan gerakan literasi pada masyarakat di RT 003 kampung Choblong Desa Cibereum Cisarua Bogor dan RT 002 Desa Sukamanah Mega Mendung Bogor Jawa Barat, maka masyarakat akan semakin Membaca semakin penting dalam kehidupan masyarakat yang semakin kompleks. Setiap aspek kehidupan melibatkan kegiatan membaca. kemampuan membaca merupakan tuntutan realitas kehidupan sehari-hari manusia. Beribu judul buku dan berjuta Koran diterbitkan setiap hari. Walaupun informasi bisa ditemukan dari media lain seperti televisi dan radio, namun peran membaca tak dapat digantikan sepenuhnya. Membaca tetap memegang peranan penting dalam kehidupan sehari-hari karena tidak semua informasi bisa didapatkan dari media televisi dan radio. Keluarga merupakan pusat pembelajaran, oleh karenanya Gerakan Literasi harus dimulai pada tingkat yang paling kecil di masyarakat yaitu di dalam keluarga. Gerakan Literasi bukan hanya tanggung jawab pemerintah namun keluarga, sekolah, dan masyarakat menjadi penopang bagi berhasilnya gerakan literasi.
\end{abstract}

Kata kunci: Pengenalan, Literasi, masyarakat

\begin{abstract}
Literacy culture must continue to be developed considering that through reading the quality of education can be created. By introducing literacy movements to the community in RT 003 Choblong village, Cibereum Village, Cisarua Bogor and RT 002 Mega Mendung Bogor Village, West Java, the community will increasingly read more important in the increasingly complex community life. Every aspect of life involves reading. the ability to read is a demand for the reality of everyday human life. Thousands of titles and millions of newspapers are published every day. Although information can be found from other media such as television and radio, the role of reading cannot be completely replaced. Reading still plays an important role in everyday life because not all information can be obtained from television and radio media. Family is the center of learning, therefore the Literacy Movement must begin at the smallest level in the community, namely in the family. The Literacy Movement is not only the responsibility of the government, but families, schools and communities are the pillars of the success of the literacy movement.
\end{abstract}

Key words: Introduction, Literacy, Community

Correspondence author: Sanusi, sanusiunindra@gmail.com, Indonesia

(i) (5)

This work is licensed under a CC-BY-NC

\section{PENDAHULUAN}

Bila kita melihat pada tingginya persaingan dalam era globalisasi yang kian kompetitif ini, pendidikan yang sangat berkualitas sangat dibutuhkan. Untuk 
menciptakan dunia pendidikan yang lebih berkualitas, maka pastilah terdapat banyak faktor yang saling berkaitan dan saling memengaruhi. Salah satu upaya yang dilakukan oleh pemerintah Republik Indonesia untuk menciptakan pendidikan yang lebih berkualitas adalah melalui Gerakan Literasi Nasional. Gerakan ini berupaya untuk meningkatkan budaya literasi (membaca dan menulis).

Pemerintah melalui Permendikbud Nomor 23 tahun 2015 telah menyadari pentingnya penumbuhan karakter peserta didik melalui kebijakan membaca selama 15 menit sebelum pelajaran dimulai. Namun untuk menumbuhkan dan meningkatkan budaya literasi (membaca dan menulis) tidaklah mudah ataupun dapat dilakukan secara instan, diperlukan usaha yang terus menerus dan pembiasaan agar budaya literasi ini dapat tumbuh dan meningkat. Semua elemen harus saling membantu, baik dalam keluarga, sekolah, masyarakat, maupun pemerintah. Hal ini juga membutuhkan konsistensi.

Bila kita melihat fenomena yang terjadi sekarang ini, yang menjadi daya tarik bagi anak-anak, orang tua, masyarakat Indonesia bukanlah buku melainkan televisi ataupun gawai (gadget). Untuk memulai kebiasaan dalam budaya membaca ini harus dimulai dari unit terkecil yaitu, keluarga. Dengan membaca kita bisa mendapatkan ilmu didapatkan dari buku. Selain itu membaca merupakan perintah dari Allah SWT, seperti yang tertuang dalam QS Al-Alaq (96) ayat 1-5. Yakni, "Bacalah dengan nama Tuhanmu Yang Menciptakan. Dia telah menciptakan manusia dari segumpal darah. Bacalah, dan Tuhanmulah Yang Maha Pemurah. Yang mengajarkan (manusia) dengan perantaraan kalam. Dia mengajarkan kepada manusia apa yang tidak diketahuinya." Pendidikan agama dimulai dari keluarga, oleh karena itu kebiasaan membaca dimulai dari rumah/ keluarga. Selain keluarga, membangun budaya membaca harus dimulai dari Sekolah, karena sekolah berperan sangat penting dalam meningkatkan dan mengembangkan potensi siswa.

Saat ini budaya membaca harus terus dikembangkan mengingat bahwa melalui membaca maka kualitas pendidikan yang tinggi dapat tercipta. Semua elemen harus saling bantu-membantu agar kebiasaan membaca ini menjadi suatu kebutuhan baik di tingkat keluarga, sekolah, maupun masyarakat. Gerakan Literasi bukan hanya tanggung jawab pemerintah namun keluarga, sekolah, dan masyarakat menjadi penopang bagi berhasilnya gerakan literasi.

Berdasarkan pada ulasan di atas kami bermaksud untuk melaksanakan kegiatan pengabdian kepada masyarakat berupa Pengenalan Gerakan Literasi pada Masyarakat di RT 003 kampung Choblong Desa Cibereum Cisarua Bogor dan RT 002 Desa Sukamanah Mega Mendung Bogor Jawa Barat. Alasan utama dipilihnya tempat 2 mitra ini karena setelah melakukan kunjungan ke dua mitra kami tersebut kami memperoleh data melalui angket yang telah kami sebar mengenai budaya literasi pada kedua mitra masih sangat rendah. Maka untuk mendorong budaya membaca pada masyarakat di kedua mitra tersebut kami berencana untuk mengenalkan gerakan literasi yang saat ini memang sedang digalakkan pemerintah, agar para orang tua khususnya dapat menerapkan gerakan literasi di rumah, dalam hal ini elemen keluarga.

\section{METODE PELAKSANAAN}

Pemilihan mitra kegiatan ini didasarkan atas kebutuhan mitra Berkaca dari analisis situasi di atas, maka alasan utama dipilihnya 2 mitra ini karena setelah melakukan kunjungan ke dua mitra kami tersebut kami memperoleh data melalui angket 
yang telah kami sebar mengenai budaya literasi pada kedua mitra masih sangat rendah. Maka untuk mendorong budaya membaca pada masyarakat di kedua mitra tersebut kami berencana untuk mengenalkan gerakan literasi yang saat ini memang sedang digalakkan pemerintah, agar para orang tua khususnya dapat menerapkan gerakan literasi di rumah, dalam hal ini elemen keluarga. Oleh karena itu kami bermaksud untuk melaksanakan kegiatan pengabdian kepada masyarakat berupa Pengenalan Gerakan Literasipada Masyarakat di RT 003 kampung Choblong Desa Cibereum Cisarua Bogor dan RT 002 Desa Sukamanah Mega Mendung Bogor Jawa Barat.Untuk mengatasi kekhawatiran tersebut mitra meminta kesedian kami untuk melakukan Pengenalan Gerakan Literasipada Masyarakat. Kami berencana mengadakan pengenalan tersebut, untuk lebih menumbuhan budaya dan minat membaca pada masyarakat, karena berdasarkan angket yang kami telah sebar budaya membaca masyarakat di RT 003 kampung Choblong Desa Cibereum Cisarua Bogor dan RT 002 Desa Sukamanah Mega Mendung Bogor Jawa Barat masih sangat rendah. Semua elemen harus saling bantumembantu agar kebiasaan membaca ini menjadi suatu kebutuhan baik di tingkat keluarga, sekolah, maupun masyarakat. Gerakan Literasi bukan hanya tanggung jawab pemerintah namun keluarga, sekolah, dan masyarakat menjadi penopang bagi berhasilnya gerakan literasi.

Pendekatan yang dilakukan dalam kegiatan pengabdian masyarakat ini adalah dengan melakukan:

1. Pemberian angket tentang Gerakan Literasi pada Masyarakat di RT 003 kampung Choblong Desa Cibereum Cisarua Bogor dan RT 002 Desa Sukamanah Mega Mendung Bogor Jawa Barat.

2. Presentasi pengenalan tentang Gerakan Literasi pada Masyarakat di RT 003 kampung Choblong Desa Cibereum Cisarua Bogor dan RT 002 Desa Sukamanah Mega Mendung Bogor Jawa Barat.

3. Tanya jawab tentang Gerakan Literasi pada Masyarakat di RT 003 kampung Choblong Desa Cibereum Cisarua Bogor dan RT 002 Desa Sukamanah Mega Mendung Bogor Jawa Barat.

\section{HASIL DAN PEMBAHASAN}

Hasil kegiatan ini adalah masyarakat sangat antusias ketika kami memberikan Pengenalan Gerakan Literasipada Masyarakat di RT 003 kampung Choblong Desa Cibereum Cisarua Bogor dan RT 002 Desa Sukamanah Mega Mendung Bogor Jawa Barat, budaya literasi pada kedua mitra masih sangat rendah. Stelah kami memberikan pengenalan kepada para masyarakat bahwa budaya literasi harus ditingkatkan. Dalam hal ini, kami memberikan pengenalan tentang pentingnya membaca. Membaca merupakan salah satu fungsi yang paling penting dalam hidup. Semua proses belajar didasarkan pada kemampuan membaca. Dengan kemampuan membaca yang membudaya dalam diri setiap anak, maka tingkat keberhasilan di sekolah maupun dalam kehidupan di masyarakat akan membuka peluang kesuksesan hidup yang lebih baik. Membaca sangat erat kaitanya dengan kegiatan tulis menulis,pada tahap perkembangan awal manusia menulis untuk menumpahkan ide atau gagasan, memberikan informasi seputar kehidupannya, memberikan kabar berita dll. Sebelum ditemukannya kertas orang orang pada zaman dahulu biasa menulis di atas kulit hewan, diatas daun atau kulit pohon yang dikeringkan dll. Dengan membaca kita dapat mendapatkan informasi atau mengetahui isi dari tulisan tersebut. 
Banyak sekali manfaat atau keuntungan yang dapat kita raih dengan membaca buku terutama sekali bagi anda yang memiliki anak biasakanlah sejak dini untuk gemar membaca buku tentu saja buku buku yang bermanfaat bagi anak anda seperti buku pelajaran, buku cerita atau dongeng yang banyak mengandung pesan moral, buku sejarah dll. Ternyata membaca buku sejak dini ada banyak sekali manfaatnya. Selain bisa memperkenalkan kosakata dan mempelajari atraksi verbal, manfaat membaca buku juga dapat memancing imajinasi anak. Membaca buku juga ternyata memiliki manfaat untuk melatih keterampilan motorik kasar dan visual anak, yaitu dengan melatih membuka halaman buku. Yang paling penting adalah dapat menciptakan bonding atau ikatan yang lebih erat dengan orang tuanya. Kebersamaan yang tercipta saat kita membacakan cerita pada anak akan memberinya rasa aman, dicintai, dan diperhatikan. Selain itu, ekspresi dan intonasi suara kita juga dapat mengajarkannya rupa-rupa emosi manusia. Isi kegiatan sehari hari anak anda dengan banyak membaca buku. Manfaat yang diperoleh anak yang telah membiasakan membaca sejak dini adalah:

1. anak yang gemar membaca tentu akan mendapatkan informasi atau pengetahuan yang lebih banyak dibandingkan dengan anak yang jarang membaca

2. anak dapat memanfaatkan waktu luang dengan kegiatan yamg lebih bermanfaat dengan semakin banyaknya informasi yang diterima dapat menambah wawasan berpikir anak tersebut

3. anak yang gemar membaca khususnya membaca buku buku pelajaran tentu saja dapat meningkatkan prestasi belajar anak tersebut

4. anak yang gemar membaca buku khususnya buku buku cerita yang banyak mengandung pesan moral dapat membentuk prilaku anak tersebut menjadi lebih baik dikehidupan sehari hari.

Anak yang terbiasa membaca buku di rumah akan menumbuhkan semangat rajin belajar, biasakanlah kepada anak anda untuk mengulang kembali pelajaran yang telah diterimanya di sekolah dengan belajar di rumah. Membaca adalah kegiatan yang mempunyai banyak manfaat. Contohnya adalah menambah pengetahuan, hiburan, mengubah sudut pandang seseorang mengenai sesuatu, bahkan mengubah hidup seseorang. Masih banyak manfaat yang ditimbulkan dari kegiatan ini. dari banyaknya manfaat itu, dapat disimpulkan membaca adalah kegiatan yang positif. Hal itu terlepas dari baik-buruknya buku tersebut. Seburuk apapun buku, pasti akan memberi pesan yang baik untuk pembacanya.

Menumbuhkan minat baca sejak dini adalah pilihan yang tepat. Karena usia anakanak adalah usia emas dalam hidup seseorang. Jika kebiasaan membaca menjadi kegemaran anak, maka tidak heran anak tersebut menjadi individu yang berkualitas. Individu yang lebih baik daripada yang tidak menyukai membaca. Individu yang mengharumkan bangsa, negara, agama, keluarga, dan pastinya kedua orang tua.

Membiasakan anak membaca sedari dini mampu menghindarkan anak dari kegiatan yang tidak berguna, yang dapat merugikan dirinya dan oranglain. Hal itu seperti: bermain Play Station (PS) atau game online, berkelahi, mengganggu teman, berbuat onar, dan sebagainya.

Setelah kami memberikan Pengenalan tersebut para masyarakat sangat antusias dan sangat mengupayakan untuk memulai gerakan literasi pada keluarga mereka di rumah. 


\section{SIMPULAN}

Saat ini budaya membaca harus terus dikembangkan mengingat bahwa melalui membaca maka kualitas pendidikan yang tinggi dapat tercipta. Semua elemen harus saling bantu-membantu agar kebiasaan membaca ini menjadi suatu kebutuhan baik di tingkat keluarga, sekolah, maupun masyarakat. Gerakan Literasi bukan hanya tanggung jawab pemerintah namun keluarga, sekolah, dan masyarakat menjadi penopang bagi berhasilnya gerakan literasi. Dengan mengenalkan gerakan literasi pada masyarakat di di RT 003 kampung Choblong Desa Cibereum Cisarua Bogor dan RT 002 Desa Sukamanah Mega Mendung Bogor Jawa Barat, maka masyarakat akan semakin Membaca semakin penting dalam kehidupan masyarakat yang semakin kompleks. Setiap aspek kehidupan melibatkan kegiatan membaca. kemampuan membaca merupakan tuntutan realitas kehidupan sehari-hari manusia. Beribu judul buku dan berjuta Koran diterbitkan setiap hari. Walaupun informasi bisa ditemukan dari media lain seperti televisi dan radio, namun peran membaca tak dapat digantikan sepenuhnya. Membaca tetap memegang peranan penting dalam kehidupan sehari-hari karena tidak semua informasi bisa didapatkan dari media televisi dan radio. Keluarga merupakan pusat pembelajaran, oleh karenanya Gerakan Literasi harus dimulai pada tingkat yang paling kecil di masyarakat yaitu di dalam keluarga. Gerakan Literasi bukan hanya tanggung jawab pemerintah namun keluarga, sekolah, dan masyarakat menjadi penopang bagi berhasilnya gerakan literasi.

\section{DAFTAR PUSTAKA}

Permendikbud Nomor 23 tahun 2015

QS Al-Alaq (96) ayat 1-5.

http//:www.kemendikbud.go.id 